\title{
PENGARUH KEPEMIMPINAN, MOTIVASI KERJA DAN KOMUNIKASI TERHADAP KINERJA PEGAWAI PADA DINAS LINGKUNGAN HIDUP DAN KEBERSIHAN KABUPATEN KARAWANG
}

\author{
Agus Mustaqim \\ Universitas Singaperbangsa Karaawang \\ Agus.mustaqim@yahoo.co.id
}

\begin{abstract}
ABSTRAK
Penelitian ini bertujuan untuk mengetahui, menjelaskan dan menganalisis Kepemimpinan, Motivasi Kerja Dan Komunikasi Terhadap Kinerja Pegawai serta pengaruh parsial dan simultan Kepemimpinan, Motivasi Kerja Dan Komunikasi Terhadap Kinerja Pegawai Pada Dinas Lingkungan Hidup Dan Kebersihan Kabupaten Karawang. Jumlah sampel yang diambil sebanyak 151 pegawai dengan teknik sampling jenuh. Tesis ini diharapkan dapat memberikan sumbangan bagi pengembangan bidang manajemen khususnya manajemen sumber daya manusia. Metode penelitian yang digunakan penulis dalam penulisan ini menggunakan metode deskriptif dan verifikatif, dari hasil analisis data penelitian diperoleh beberapa kesimpulan sebagai berikut: (1) Kepemimpinan $\left(\mathrm{X}_{1}\right)$ di Dinas Lingkungan Hidup Dan Kebersihan sudah sesuai kebutuhan pegawai, Motivasi $\left(\mathrm{X}_{2}\right)$ di Dinas Lingkungan Hidup yang di berikan kepada pegawai sudah baik, Komunikasi $\left(\mathrm{X}_{3}\right)$ di Dinas Lingkungan Hidup sudah berjalan dengan baik, Kinerja Pegawai (Y) di Dinas Lingkungan Hidup sudah memiliki kinerja yang baik. (2) Koefisien korelasi antara variabel bebas yaitu Kepemimpinan $\left(\mathrm{X}_{1}\right)$ dan Motivasi $\left(\mathrm{X}_{2}\right)$, kemudian Motivasi $\left(\mathrm{X}_{2}\right)$ dan Komunikasi $\left(\mathrm{X}_{3}\right)$ serta Kepemimpinan $\left(\mathrm{X}_{1}\right)$ dan Komunikasi $\left(\mathrm{X}_{3}\right)$ ketiga variable bebas tersebut memiliki tingkat hubungan yang kuat dan searah karena nilai positif.(3)Kepemimpinan secara parsial mempunyai pengaruh yang positif dan signifikan terhadap Kinerja. Kepemimpinan lebih banyak memberikan pengaruh terhadap Kinerja dibandingkan variabel Motivasi dan Komunikasi. (4)Motivasi secara parsial mempunyai pengaruh yang positif dan signifikan terhadap Kinerja (5) Komunikasi secara parsial mempunyai pengaruh yang positif dan signifikan terhadap Kinerja. (6) Kepemimpinan $\left(X_{1}\right)$, Motivasi $\left(\mathrm{X}_{2}\right)$ dan Komunikasi $\left(\mathrm{X}_{3}\right)$ secara simultan berpengaruh positif dan signifikan terhadap Kinerja Pegawai (Y).
\end{abstract}

Kata Kunci: Kepemimpinan, Motivasi, Komunikasi, Kinerja

\section{A. PENDAHULUAN}

Tugas Pokok dari Dinas Lingkungan Hidup dan Kebersihan diatur dalam Pasal 3, yaitu: Dinas Lingkungan Hidup dan Kebersihan mempunyai tugas pokok melaksanakan sebagian urusan pemerintah daerah di Bidang Lingkungan Hidup, serta tugas pembantuan yang ditugaskan kepada Pemerintah Daerah. Fungsi dari Dinas Lingkungan Hidup dan Kebersihan diatur dalam Pasal 4, Yaitu :penyusunan kebijakan teknis operasional dan/atau bahan kebijakan pemerintah daerah di Bidang Lingkungan Hidup; penyelenggaraan urusan pemerintah daerah di Bidang Lingkungan Hidup; dan pembinaan penyelenggaraan urusan pemerintah daerah di Bidang Lingkungan Hidup.

Kepala dinas sebagai pimpinan tertinggi sangat berpengaruh dalam menentukan organisasi yang dipimpinnya. Kepemimpinan yang baik harus dapat mengupayakan peningkatan kinerja pegawainya. Susiati Purwaning Utami (2010) dalam penelitiannya menyatakan bahwa terdapat hubungan positif kuat dan signifikan antara kepemimpinan terhadap kinerja. Kemudian didukung oleh penelitian Rahmat Sugianto (2010) 
menyatakan bahwa Terdapat pengaruh kepemimpinan manajerial terhadap kinerja. Berikut adalah data hasil penelitian pendahuluan melalui penyebaran kuesioner kepada 30 responden pada Dinas Lingkungan hidup dan kebersihan kabupaten karawang.

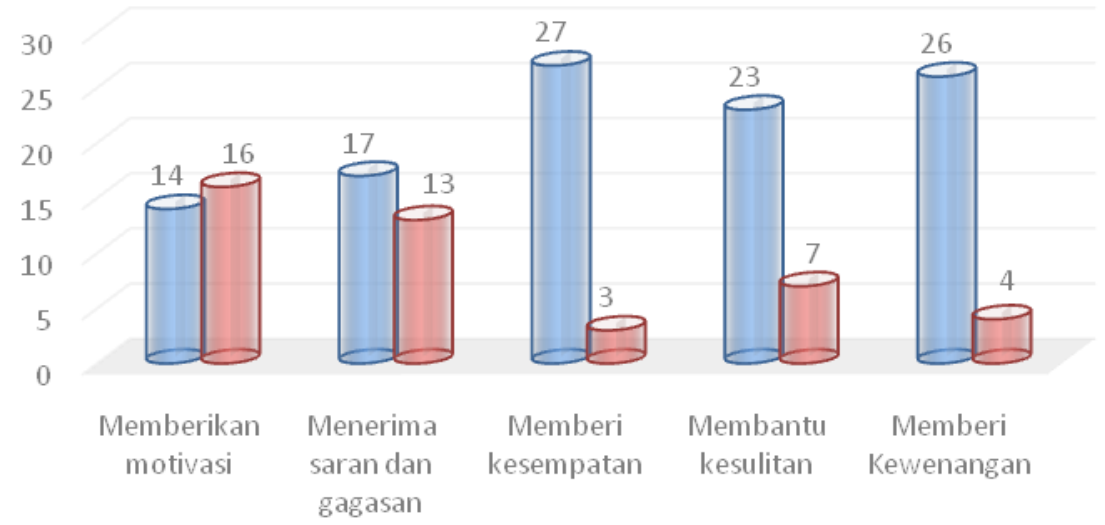

Sumber: Penelitian Pendahuluan 2017

\section{Gambar 1}

\section{Hasil Penelitian Pendahuluan Kepemimpinan}

Berdasarkan data diatas dapat ditarik kesimpulan bahwa beberapa pegawai merasa pemimpin kurang memberikan motivasi serta saran dan gagasan dari pegawai kurang begitu diperhatikan. Hal ini membuktikan bahwa kinerja masih rendah.

Motivasi merupakan sumber penggerak yang erat kaitannya dengan kualitas kerja dalam organisasi. Motivasi kerja para karyawan merupakan hal yang sangat penting, agar mereka bekerja dengan semangat untuk melaksanakan tugasnya. Pemimpin harus dapat mendorong anggotanya agar dapat melaksanakan tugas; dan untuk itu diperlukan penguasaan kemampuan untuk memotivasi. Dinas Lingkungan Hidup dan Kebersihan Kabupaten Karawang telah berusaha melakukan dorongan dengan memberikan motivasi kepada pegawainya, walaupun pada kenyataanya masih belum optimal, karena setiap individu mempunyai keinginan dan kebutuhan yang berbeda. Windy Aprilia Murty dan Gunasti Hudiwinarsih (2012) dalam penelitiannya menyatakan bahwa motivasi berpengaruh positif dan signifikan terhadap kinerja pegawai. Selanjutnya hasil penelitian Ririvega kasenda (2013) menyatakan bahwa Motivasi berpengaruh signifikan terhadap kinerja karyawan nilai koefisien adalah positif. Berikut adalah data hasil penelitian pendahuluan mengenai motivasi kerja melalui penyebaran kuesioner kepada tiga puluh orang responden.

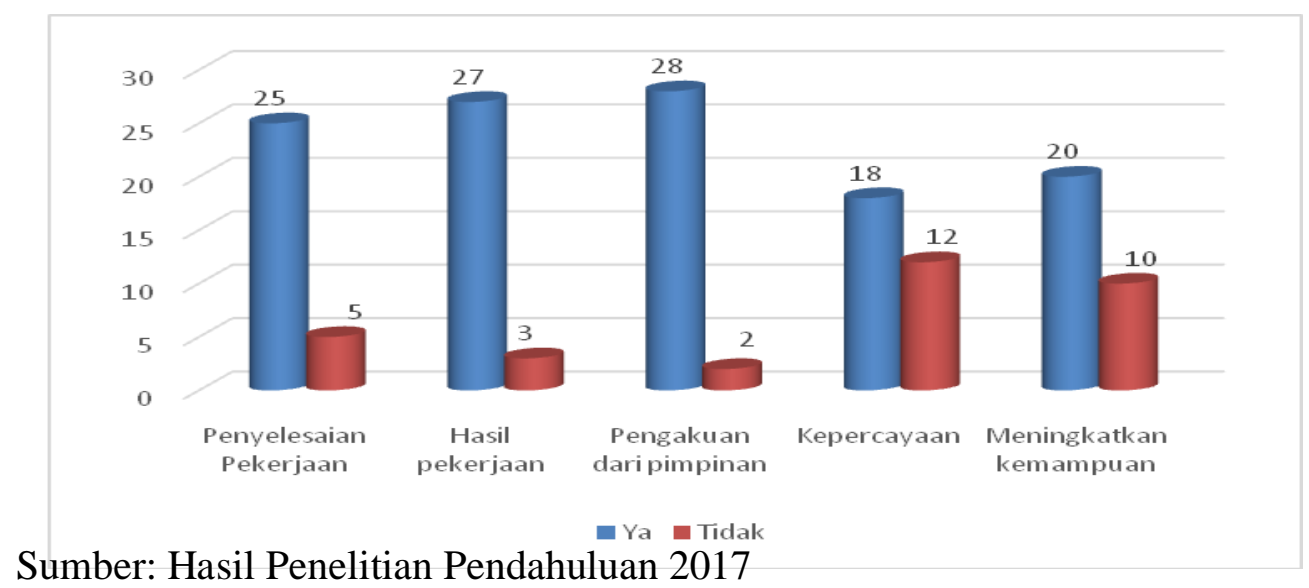

Sumber: Hasil Penelitian Pendahuluan 2017

Gambar 2

Hasil Penelitian pendahuluan Motivasi Kerja 
Berdasarkan data diatas dapat diatarik kesimpulan bahwa masih ada beberapa pegawai yang merasa bahwa kurang diberikan kepercayaan untuk yang penuh dalam menjalankan tugas sehari-hari serta dalam hal peningkatan kemampuan kurang mendapatkan kesempatan.

Komunikasi adalah suatu proses penyampaian informasi (pesan, ide, gagasan) dari satu pihak kepada pihak lain. Pada umumnya, komunikasi dilakukan secara lisan atau verbal yang dapat dimengerti oleh kedua belah pihak. apabila tidak ada bahasa verbal yang dapat dimengerti oleh keduanya. Menurut Vietzhal Rivai (2011:130), kemampuan berkomunikasi seorang pemimpin memegang peranan yang penting, karena seorang pemimpinan akan berhadapan dengan bermacam-macam pribadi yang berbeda watak dan latar belakangnya, Hal ini perlu disadari oleh seorang pemimpin, sehingga pemimpin akan berusaha memahami pribadi serta watak bawahannya. Komunikasi yang dilakukan oleh seorang pemimpin dapat berbentuk instruksi atau perintah, saran, bimbingan, petunjuk, nasihat, maupun kritik yang sifatnya membangun, Di samping komunikasi dari atas yang dilakukan oleh pemimpin, maka komunikasi dari bawah juga sangat penting untuk diperhatikan, Komunikasi dari bawah bisa berupa laporan, keluhan, harapan-harapan, serta penyampaian ide-ide yang perlu mendapat perhatian, karena hal semacam ini sering lepas dari perhatian Pemimpin tidak cukup hanya memiliki kemampuan membuat komitmen atau keputusan di dalam proses berpikir. Berikut adalah hasil penelitian pendahuluan tentang komunikasi kepada 30 orang responden pada Dinas Lingkungan Hidup dan Kebersihan kabupaten Karawang.

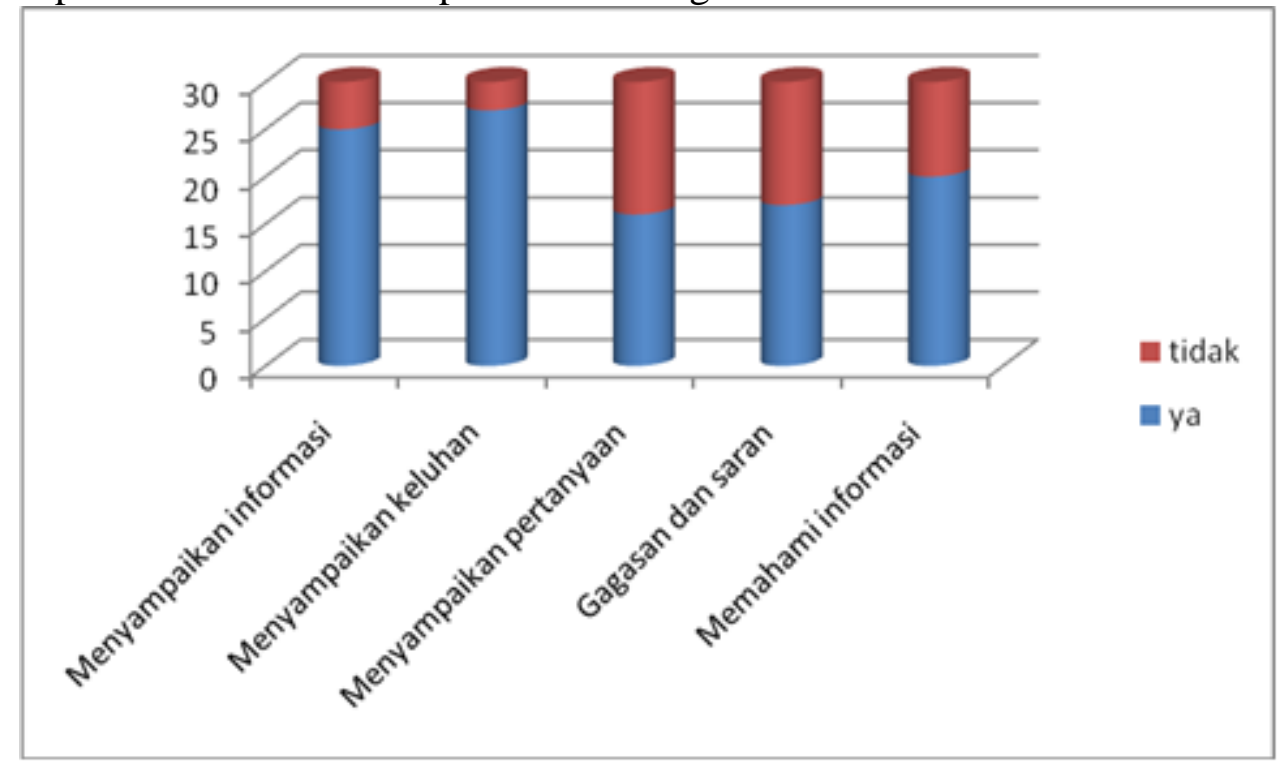

Sumber: Hasil Penelitian Pendahuluan 2017

Gambar 3

Hasil Penelitian Pendahuluan Komunikasi

Berdasarkan data diatas dapat diatarik kesimpulan bahwa masih ada beberapa pegawai yang merasa bahwa dalam menyampaikan pertanyaan mengenai pekerjaan serta pemberian gagasan dan saran kurang diterima dengan baik.

Kinerja adalah pencapaian atas tujuan organisasi yang dapat berbentuk output kuantitatif maupun kualitatif, kreativitas, fleksibilitas, dapat diandalkan, atau hal-hal lain yang diinginkan oleh organisasi. Kinerja pegawai yang optimal dipengaruhi oleh berbagai faktor, baik internal maupun eksternal. Stinsone Jahson dalam Robert Balton dalam Soelaiman Sukmalana (2009:262) menyatakan bahwa kinerja dan mencapai kinerja terkait dengan perilaku pimpinan, dimana perilaku hubungan dinilai lebih penting apabila para bawahan melaksanakan tugas-tugas terstruktur. Tetapi kadar perilaku tugas yang harus 
digunakan pemimpin bergantung pada hakikat staff atau bawahan serta jenis tugas yang dikerjakan. Berikut ini adalah data mengenai rekapitulasi kehadiran selama tahun 2016 dapat dilihat pada tabel dibawah ini.

Tabel 1

Rekapitulasi Kehadiran Pegawai tahun 2016

\begin{tabular}{|c|l|c|c|c|}
\hline No & \multicolumn{1}{|c|}{ Bulan } & $\begin{array}{c}\text { Kehadiran } \\
\text { Rata-rata }\end{array}$ & $\begin{array}{c}\text { Target } \\
\text { Kehadiran }\end{array}$ & $\begin{array}{c}\text { Kehadiran } \\
\text { Terendah }\end{array}$ \\
\hline 1. & JANUARI & $89,7 \%$ & $100 \%$ & $23,4 \%$ \\
\hline 2. & FEBRUARI & $87,9 \%$ & $100 \%$ & $42,9 \%$ \\
\hline 3. & MARET & $86,8 \%$ & $100 \%$ & $47,6 \%$ \\
\hline 4 & APRIL & $89,2 \%$ & $100 \%$ & $10,0 \%$ \\
\hline 5 & MEI & $90,1 \%$ & $100 \%$ & $57,0 \%$ \\
\hline 6 & JUNI & $94,0 \%$ & $100 \%$ & $19,0 \%$ \\
\hline 7 & JULI & $91,3 \%$ & $100 \%$ & $50 \%$ \\
\hline 8 & AGUSTUS & $86,2 \%$ & $100 \%$ & $10,5 \%$ \\
\hline 9 & SEPTEMBER & $90,3 \%$ & $100 \%$ & $5,0 \%$ \\
\hline 10 & OKTOBER & $91 \%$ & $100 \%$ & $36.4 \%$ \\
\hline 11 & NOVEMBER & $88,6 \%$ & $100 \%$ & $25,00 \%$ \\
\hline 12 & DESEMBER & $90,3 \%$ & $100 \%$ & $61,10 \%$ \\
\hline
\end{tabular}

Sumber: DLHK Kabupaten Karawang

Dari data tersebut diatas memperlihatkan bahwa tingkat kehadiran Pegawai Dinas Lingkungan Hidup dan Kebersihan Kabupaten Karawang masih belum optimal. Masih adanya pegawai yang tingkat kehadirannya minim dan tidak hadir tanpa keterangan

\section{B. TINJAUAN PUSTAKA}

\section{Kinerja Pegawai}

Menurut A.A. Anwar Prabu Mangkunegara, (2011: 67), mengatakan Istilah Kinerja berasal dari kata Job Performance atau Actual Performance (prestasi kerja atau prestasi sesungguhnya dicapai oleh seseorang). Pengertian Kinerja (prestasi kerja) adalah hasil kerja secara kualitas dan kuantitas yang dicapai oleh seseorang Pegawai dalam melaksanakan tugasnya sesuai dengan tanggung jawab yang diberikan kepadanya Setiap manusia mempunyai potensi untuk bertindak dalam berbagai bentuk aktivitas. Kemampuan bertindak itu diperoleh manusia baik secara alami (ada sejak lahir) atau dipelajari. Walaupun manusia mempunyai potensi untuk berperilaku tertentu, tetapi perilaku itu hanya diaktualisasi pada saat-saat tertentu. Potensi untuk berperilaku tertentu itu disebut ability (kemampuan), sedangkan ekspresi dari potensi ini dikenal sebagai performance (kinerja). Menurut Amstrong dan Baron dalam Irham Fahmi (2011:2), Kinerja adalah hasil pekerjaan yang mempunyai hubungan kuat dengan tujuan strategis organisasi, kepuasan konsumen dan memberikan kontribusi ekonomi. Kemudian Indra Bastian yang dikutip oleh Irham Fahmi (2011:2), Kinerja adalah gambaran mengenai tingkat pencapaian pelaksanaan suatu kegiatan atau program dan kebijakan dalam mewujudkan sasaran, tujuan, misi dan visi organisasi yang tertuang dalam perumusan skema strategis (strategic planning) suatu organisasi. Menurut Irham Fahmi (2011:226) bahwa kinerja adalah hasil yang diperoleh suatu organisasi baik organisasi tersebut bersifat profit oriented dan non profit oriented yang dihasilkan selama satu periode waktu. Menurut Mahsum dalam buku Masana Sembiring (2012:81) kinerja adalah gambaran mengenai tingkat pencapaian pelaksanaan suatu kegiatan / program / kebijakan dalam mewujudkan sasaran, tujuan, misi, dan visi organisasi. Menurut Riani (2011:97) bahwa kinerja adalah hasil kerja yang dapat dicapai oleh seseorang atau kelompok orang dalam suatu perusahaan sesuai dengan wewenang dan 
tanggung jawab masing-masing dalam upaya pencapaian tujuan perusahaan secara legal, tidak melanggar hukum dan tidak bertentangan dengan moral dan etika. Sedangkan menurut Armstrong dan Baron dalam Wibowo, (2010:2)

"kinerja adalah tentang melakukan pekerjaan dan hasil yang dicapai dari pekerjan tersebut. Kinerja adalah tentang apa yang dikerjakan dan bagaimana cara mengerjakannya. Kinerja merupakan hasil pekerjaan yang mempunyai hubungan kuat dengan tujuan strategis organisasi, kepuasan konsumen, dan memberikan kontribusi ekonomi".

Menurut Veithzal Rivai (2011:16) menyatakan bahwa: "Kinerja adalah hasil kerja yang dapat dicapai oleh seseorang atau kelompok orang dalam suatu perusahaan sesuai dengan wewenang dan tanggung jawab masing-masing dalam upaya pencapaian tujuan perusahaan secara legal, dan tidak melanggar hukum dan tidak bertentangan dengan moral atau etika". Sedangkan definisi kinerja menurut Tjutju Yunarsih dan Suwanto (2008:161) menyatakan bahwa "Kinerja merupakan prestasi yang nyata ditampilkan seseorang setelah yang bersangkutan menjalankan tugas dan perannya dalam organisasi”.

\section{Kepemimpinan}

Pemimpin merupakan unsur vital dalam sebuah organisasi, dan dalam setiap kegiatannya pemimpin di tuntut untuk memiliki kemampuan yang baik, hal tersebut terjadi karena para pemimpin membawahi sekelompok orang dalam melaksanakan tugas sehingga dapat mencapai tujuan tugas tersebut. Dengan kepemimpinan yang baik, maka peran bawahan akan berjalan dengan baik pula. Menurut Siswanto (2010:154), pengertian kepemimpinan adalah:

Sifat dan perilaku untuk mempengaruhi para bawahannya agar mereka mampu bekerja sama sehingga membentuk jalinan kerja yang harmonis dengan pertimbangan aspek efisien dan efektif untuk mencapai tingkat produktivitas kerja sesuai dengan yang telah ditetapkan.

Adapun pendapat lain yang menjelaskan mengenai kepemimpinan Menurut Ulber Silalahi (2012:310) yang mengemukakan bahwa kepemimpinan adalah "Tindakan mempengaruhi perilaku seseorang atau sekelompok orang kearah pencapaian tujuan-tujuan".

Selanjutnya Menurut Husaini Usman (2011:282) "Kepemimpinan merupakan ilmu dan seni memengaruhi orang atau kelompok untuk bertindak seperti yang diharapkan untuk mencapai tujuan secara efektif dan efisien”.

\section{Motivasi}

Menurut Stephen P. Robbins dan Mary Counter dalam buku Suwanto dan Donni Juni Priansa (2011:171) menyatakan motivasi adalah kesediaan untuk melaksanakan upaya tinggi untuk mencapai tujuan-tujuan keorganisasian yang dikondisikan oleh kemampuan upaya untuk memenuhi kebutuhan individu tertentu. Selanjutnya definisi menurut Hasibuan dalam buku Edy Sutrisno (2009:111): "Motivasi adalah pemberian daya penggerak yang menciptakan kegairahan kerja seseorang agar mereka mau bekerjasama, bekerja efektif dan terintegrasi dengan segala upayanya untuk mencapai kepuasan". Sedangkan definisi menurut Robbins dalam buku Edy Sutrisno (2009:111) mengemukakan motivasi adalah suatu kerelaan berusaha seoptimal mungkin dalam pencapaian tujuan organisasi yang dipengaruhi oleh kemampuan usaha memuaskan beberapa kebutuhan individu. Selanjutnya menurut Sondang Siagian (2008:287) yang menyatakan bahwa "Motivasi adalah dorongan untuk berbuat semaksimal mungkin dalam melaksanakan tugasnya demi mencapai keberhasilan dan tujuan organisasi, sehingga kepentingan pribadi karyawan pun akan terpelihara pula".

Selain itu pendapat ahli lain yang mengungkapkan mengenai motivasi, menurut A.A. Anwar Prabu Mangkunegara (2008:61) mengemukakan bahwa: "Motivasi merupakan kondisi atau 
energi yang menggerakkan diri karyawan yang terarah atau tertuju untuk mencapai tujuan organisasi perusahaan."

Pengertian motivasi menurut Veithzal Rivai (2011, 837), bahwa motivasi adalah serangkaian sikap dan nilai-nilai yang mempengaruhi individu untuk mencapai hal yang spesifik sesuai dengan tujuan individu. Sikap dan nilai tersebut merupakan suatu yang invisible yang memberikan kekuatan untuk mendorong individu bertingkah laku dalam mencapai tujuan, Menurut Sihotang (2007: 243), Motivasi berasal dari kata motivation, yang berarti dorongan daya batin, sedangkan to motivate artinya mendorong untuk berperilaku atau berusaha. Motivasi berhubungan dengan arah dari perilaku, kekuatan respon untuk bertindak, ketahanan perilaku dalam kurun waktu tertentu, perilaku dan prestasi.

Selanjutnya menurut Veithzal Rivai $(2011,837)$, motivasi dapat disimpulkan sebagai berikut:

1. Sebagai suatu kondisi yang menggerakan manusia ke arah suatu tujuan tertentu;

2. Suatu keahlian dalam mengarahkan Pegawai dan Perusahaan agar mau bekerja secara berhasil sehingga keinginan Pegawai dan tujuan Perusahaan sekaligus dapat tercapai;

3. Sebagai inisiasi dan pengarahan tingkah laku, pelajaran motivasi sebenarnya merupakan pelajaran tingkah laku;

4. Sebagai energi untuk membangkitkan dorongan dalam diri;

5. Sebagai kondisi yang berpengaruh membangkitkan, mengarahkan dan memelihara perilaku yang berhubungan dengan lingkungan kerja.

Menurut Sihotang (2007: 243), Motivasi berasal dari kata motivation, yang berarti dorongan daya batin, sedangkan to motivate artinya mendorong untuk berperilaku atau berusaha. Motivasi berhubungan dengan arah dari perilaku, kekuatan respon untuk bertindak, ketahanan perilaku dalam kurun waktu tertentu, perilaku dan prestasi.

\section{Komunikasi}

Pengertian komunikasi dari para ahli yang tercantum dalam buku Keith Davis dalam Mangkunegara (2011:145) mengemukakan bahwa "Communication is the transfer of infor4mation and understanding from one person to another " (Komunikasi adalah pemindahan informasi dan pemahaman dari seseorang kepada orang lain )

Edwin B Flippo dalam Mangkunegara (2011:145) menyatakan bahwa: "Communication is the act of inducting others to interpret an idea in the manner intended by the spaker or writer "(Komunikasi adalah aktivitas yang menyebabkan orang lain mengintepretasikan suatu ide, terutama yang dimaksudkan oleh pembicara atau penulis)"

Selanjutnya Andrew F. Sikula dalam Mangkunegara (2011:145) mendefinisikan sebagai berikut: "Communication is the process of transmitting information, meaning, and understanding from one person, place, or thing to another person, place, or thing" (Komunikasi adalah proses pemindahan informasi, pengertian dan pemahaman dari seseorang, suatu tempat, atau sesuatu kepada sesutu, tempat atau orang lain)

Menurut I Komang Ardana, dkk (2012:138), bahwa komunikasi merupakan kunci pembuka dapat terjadinya hubungan kerjasama antara sumber daya manusia. Dengan komunikasi seseorang dapatmenyampaikan keinginan-keinginannya yang terpendam dalam hatinya kepada orang lain, baik melalui suara, atau gerak isyarat anggota badan dan sebagainya.

Sedangkan menurut R.Wayne Pace \& Don F.Faules (2010:31) Komunikasi organisasi dapat didefinisikan sebagai pertunjukan dan penafsiran pesan di antara unit-unit komunikasi yang merupakan bagian dari suatu organisasi tertentu. Suatu organisasi terdiri dari unit-unit komunikasi dalam hubungan-hubungan hierarkis antara yang satu dengan lainnya dan berfungsi dalam satu lingkungan.

\section{Hipotesis Penelitian}


Berdasarkan uraian kerangka pemikiran di atas, maka hipotesis penelitian adalah sebagai berikut:

1. Terdapat pengaruh kepemimpinan terhadap kinerja Pegawai pada Dinas Lingkungan Hidup dan Kebersihan Kabupaten Karawang

2. Terdapat pengaruh Motivasi kerja terhadap kinerja Pegawai pada Dinas Lingkungan Hidup dan Kebersihan Kabupaten Karawang

3. Terdapat pengaruh komunikasi terhadap kinerja Pegawai pada Dinas Lingkungan Hidup dan Kebersihan Kabupaten Karawang

4. Terdapat pengaruh simultan Kepemimpinan, Motivasi kerja, dan komunikasi terhadap kinerja Pegawai pada Dinas Lingkungan Hidup dan Kebersihan Kabupaten Karawang

\section{METODE PENELITIAN DAN ANALISIS DATA}

Metode penelitian pada dasarnya merupakan cara ilmiah untuk mendapatkan data dengan tujuan dan keegunaan tertentu. Cara ilmiah kegiatan penelitian itu didasarkan pada ciri-ciri keilmuan, yaitu rasional, empiris, dan sistematis (Sugiyono 2012:2). Dalam penelitian ini menggunakan metode penelitian deskriptif dan verifikatif. Menurut Sugiyono (2012:35), penelitian deskriptif adalah penelitian yang dilakukan untuk mengetahui nilai variabel mandiri, baik satu variabel atau lebih (independent) tanpa membuat perbandingan atau menghubungkan dengan variabel yang lain. Penelitian verifikatif menurut Sugiyono (2012:3) bahwa metode penelitian kuantitatif yang digunakan untuk penelitian populasi atau sampel tertentu, dan analisis data bersifat statistik dengan tujuan untuk menguji hipotesis yang telah ditetapkan. Tujuan dari penelitian deskriptif adalah untuk memperoleh gambaran secara sistematis mengenai kepemimpinan, motivasi kerja, Komunikasi sebagai variabel bebas dan kinerja Pegawai sebagai variabel terikat, sedangkan secara verifikatif bertujuan untuk menguji hipotesis dengan perhitungan statistik.

\section{Populasi}

Populasi adalah wilayah generalisasi yang terdiri dari objek/subjek yang mempunyai kuantitas dan karakteristik tertentu yang ditetapkan oleh peneliti untuk mempelajari dan kemudian ditarik kesimpulan (Sugiono, 2012:117).

Populasi dalam penelitian ini terdiri dari seluruh pegawai pada dinas lingkungan hidup dan kebersihan kabupaten karawang, yang terdiri dari 151 orang.

\section{Sampel}

Menurut Sugiyono (2012:149) Sampel adalah bagian jumlah dan karakteristik yang dimiliki oleh populasi tersebut. Pengambilan sampel yang dilakukan didalam penelitian ini adalah dengan menggunakan metode sampling jenuh. Semua anggota populasi dijadikan sampel untuk membuat generalisasi dengan kesalahan yang relative kecil. Dengan jumlah populasi pegawai sebanyak 151 orang. Maka sampel yang digunakan sama yaitu 151 orang. (Sugiono, 2012:152).

\section{HASIL PENELITIAN \\ Profil Responden}

Responden dalam penelitian ini adalah Kantor Imigrasi Kelas II Karawang yang berjumlah 55 orang, dengan karakteristik sebagai berikut:

Tabel 2

Jumlah Responden Berdasarkan Jenis Kelamin

\begin{tabular}{|c|c|c|c|}
\hline No & Usia & Jumlah (orang) & Persentase (\%) \\
\hline 1 & Laki-laki & 131 & 86,8 \\
\hline
\end{tabular}




\begin{tabular}{|l|l|l|l|}
\hline 2 & Perempuan & 20 & 13,2 \\
\hline \multicolumn{2}{|c|}{ Total } & 151 & 151 \\
\hline
\end{tabular}

Tabel 3

Jumlah Responden Berdasarkan Usia

\begin{tabular}{|c|c|c|c|}
\hline No & Jenis Kelamin & Jumlah (orang) & Persentase (\%) \\
\hline 1 & $\begin{array}{c}\text { Dibawah 26 } \\
\text { Tahun }\end{array}$ & 25 & 16,6 \\
\hline 2 & 26-30 Tahun & 35 & 23,2 \\
\hline 3 & 31 - 35 Tahun & 30 & 19,9 \\
\hline 4 & Diatas 36 Tahun & 29 & 19,2 \\
\hline \multicolumn{2}{|r}{} & 151 & 100 \\
\hline
\end{tabular}

\section{Pengujian Keabsahan Data}

\section{Uji Validitas}

Tabel 4

Hasil Uji Validitas Variabel Kepemimpinan

\begin{tabular}{|l|c|c|c|c|}
\hline \multicolumn{1}{|c|}{ Dimensi } & $\begin{array}{c}\text { No } \\
\text { Pernyataan }\end{array}$ & r Hitung & r Kritis & Kriteria \\
\hline Memberikan informasi & 1 & 0.448 & 0.3 & Valid \\
\hline Memberikan motivasi & 2 & 0.675 & 0.3 & Valid \\
\hline $\begin{array}{l}\text { Menerima saran dan } \\
\text { gagasan }\end{array}$ & 3 & 0.518 & 0.3 & Valid \\
\hline Dukungan dari bawahan & 4 & 0.329 & 0.3 & Valid \\
\hline Memberi kesempatan & 5 & 0.436 & 0.3 & Valid \\
\hline Membantu kesulitan & 6 & 0.589 & 0.3 & Valid \\
\hline Memberi Kewenangan & 7 & 0.437 & 0.3 & Valid \\
\hline Arahan & 8 & 0.392 & 0.3 & Valid \\
\hline Koordinasi & 9 & 0.382 & 0.3 & Valid \\
\hline pengawasan & 10 & 0.373 & 0.3 & Valid \\
\hline Sumber Hasil Pengolan
\end{tabular}

Sumber: Hasil Pengolahan Data, 2017

Tabel 5

Hasil Uji Validitas Variabel Motivasi

\begin{tabular}{|l|c|c|c|c|}
\hline \multicolumn{1}{|c|}{ Dimensi } & $\begin{array}{c}\text { No } \\
\text { Pernyataan }\end{array}$ & r Hitung & r Kritis & Kriteria \\
\hline Penyelesaian Pekerjaan & 1 & 0.308 & 0.3 & Valid \\
\hline Hasil pekerjaan & 2 & 0.548 & 0.3 & Valid \\
\hline Pengakuan dari pimpinan & 3 & 0.446 & 0.3 & Valid \\
\hline Pengakuan dari Teman & 4 & 0.516 & 0.3 & Valid \\
\hline Meningkatkan kemampuan & 5 & 0.438 & 0.3 & Valid \\
\hline Inovasi & 6 & 0.563 & 0.3 & Valid \\
\hline Bijaksana & 7 & 0.417 & 0.3 & Valid \\
\hline Kepuasan Kerja & 8 & 0.589 & 0.3 & Valid \\
\hline Sifat sosial & 9 & 0.520 & 0.3 & Valid \\
\hline Kepercayaan & 10 & 0.398 & 0.3 & Valid \\
\hline
\end{tabular}




\begin{tabular}{|l|c|c|c|c|}
\hline Interaksi & 11 & 0.539 & 0.3 & Valid \\
\hline
\end{tabular}

Sumber: Hasil Pengolahan Data, 2017

Tabel 6

Hasil Uji Validitas Variabel Komunikasi

\begin{tabular}{|l|c|c|c|c|}
\hline \multicolumn{1}{|c|}{ Dimensi } & $\begin{array}{c}\text { No } \\
\text { Pernyataan }\end{array}$ & r Hitung & r Kritis & Kriteria \\
\hline Informasi Pekerjaan & 1 & 0.388 & 0.3 & Valid \\
\hline Dasar Pemikiran & 2 & 0.364 & 0.3 & Valid \\
\hline Kebijakan & 3 & 0.405 & 0.3 & Valid \\
\hline Kinerja Pegawai & 4 & 0.569 & 0.3 & Valid \\
\hline Rasa Memiliki & 5 & 0.560 & 0.3 & Valid \\
\hline $\begin{array}{l}\text { Menyampaikan } \\
\text { informasi }\end{array}$ & 6 & 0.534 & 0.3 & Valid \\
\hline Menyampaikan keluhan & 7 & 0.567 & 0.3 & Valid \\
\hline $\begin{array}{l}\text { Menyampaikan } \\
\text { pertanyaan }\end{array}$ & 8 & 0.468 & 0.3 & Valid \\
\hline Gagasan dan saran & 9 & 0.496 & 0.3 & Valid \\
\hline Memahami informasi & 10 & 0.519 & 0.3 & Valid \\
\hline Koordinasi Tugas & 11 & 0.503 & 0.3 & Valid \\
\hline $\begin{array}{l}\text { Hubungan Antar } \\
\text { Pribadi }\end{array}$ & 12 & 0.449 & 0.3 & Valid \\
\hline $\begin{array}{l}\text { Informasi mulut ke } \\
\text { mulut }\end{array}$ & 13 & 0.333 & 0.3 & Valid \\
\hline
\end{tabular}

Sumber: Hasil Pengolahan Data, 2017

Tabel 7

Hasil Uji Validitas Variabel Kinerja

\begin{tabular}{|l|c|c|c|c|}
\hline \multicolumn{1}{|c|}{ Dimensi } & $\begin{array}{c}\text { No } \\
\text { Pernyataan }\end{array}$ & r Hitung & r Kritis & Kriteria \\
\hline $\begin{array}{l}\text { Pekerjaan yang } \\
\text { diselesaikan }\end{array}$ & 1 & 0.424 & 0.3 & Valid \\
\hline Ketepatan & 2 & 0.417 & 0.3 & Valid \\
\hline Kecermatan & 3 & 0.501 & 0.3 & Valid \\
\hline Kelengkapan & 4 & 0.575 & 0.3 & Valid \\
\hline Keahlian & 5 & 0.486 & 0.3 & Valid \\
\hline Keterampilan & 6 & 0.374 & 0.3 & Valid \\
\hline Penyelesaian masalah & 7 & 0.724 & 0.3 & Valid \\
\hline Rekan kerja & 8 & 0.659 & 0.3 & Valid \\
\hline Atasan & 9 & 0.414 & 0.3 & Valid \\
\hline Dapat dipercaya & 10 & 0.571 & 0.3 & Valid \\
\hline Kehadiran & 11 & 0.469 & 0.3 & Valid \\
\hline Semangat kerja & 12 & 0.621 & 0.3 & Valid \\
\hline Tanggung jawab & 13 & 0.528 & 0.3 & Valid \\
\hline Integritas & 14 & 0.478 & 0.3 & Valid \\
\hline
\end{tabular}

Sumber: Hasil Pengolahan Data, 2017 


\section{Uji Reliabilitas}

Tabel 8

Hasil Uji Reliabilitas

\begin{tabular}{|c|l|c|c|c|}
\hline No & \multicolumn{1}{|c|}{ Variabel } & r Hitung & r Kritis & Keterangan \\
\hline 1 & Kepemimpinan $\left(\mathrm{X}_{1}\right)$ & 0.784 & 0.70 & $\begin{array}{c}\text { Sangat } \\
\text { Reliabel }\end{array}$ \\
\hline 2 & Motivasi $\left(\mathrm{X}_{2}\right)$ & 0.817 & 0.70 & $\begin{array}{c}\text { Sangat } \\
\text { Reliabel }\end{array}$ \\
\hline 3 & Komunikasi $\left(\mathrm{X}_{3}\right)$ & 0.830 & 0.70 & $\begin{array}{c}\text { Sangat } \\
\text { Reliabel }\end{array}$ \\
\hline 3 & Kinerja (Y) & 0.862 & 0.70 & $\begin{array}{c}\text { Sangat } \\
\text { Reliabel }\end{array}$ \\
\hline
\end{tabular}

Sumber : Hasil pengolahan data, 2017

\section{Uji Normalitas}

Tabel 9

Hasil Uji Normalitas

\begin{tabular}{|c|c|c|c|}
\hline \multirow{2}{*}{ Variabel } & \multicolumn{2}{|c|}{ Kolmogrov - Smirnov } & \multirow{2}{*}{ Keterangan } \\
\hline & r Hitung & r Kritis & \\
\hline Kepemimpinan $\left(\mathrm{X}_{1}\right)$ & 0.072 & 0.05 & $\begin{array}{c}\text { Distribusi } \\
\text { Normal }\end{array}$ \\
\hline Motivasi $\left(\mathrm{X}_{2}\right)$ & 0.077 & 0.05 & $\begin{array}{c}\text { Distribusi } \\
\text { Normal }\end{array}$ \\
\hline Komunikasi $\left(\mathrm{X}_{3}\right)$ & 0.058 & 0.05 & $\begin{array}{c}\text { Distribusi } \\
\text { Normal }\end{array}$ \\
\hline Kinerja $(\mathrm{Y})$ & 0.102 & 0.05 & $\begin{array}{c}\text { Distribusi } \\
\text { Normal }\end{array}$ \\
\hline
\end{tabular}

Sumber: Hasil pengolahan data, 2017

\section{E. PEMBAHASAN HASIL TEMUAN PENELITIAN}

\section{Persamaan Jalur}

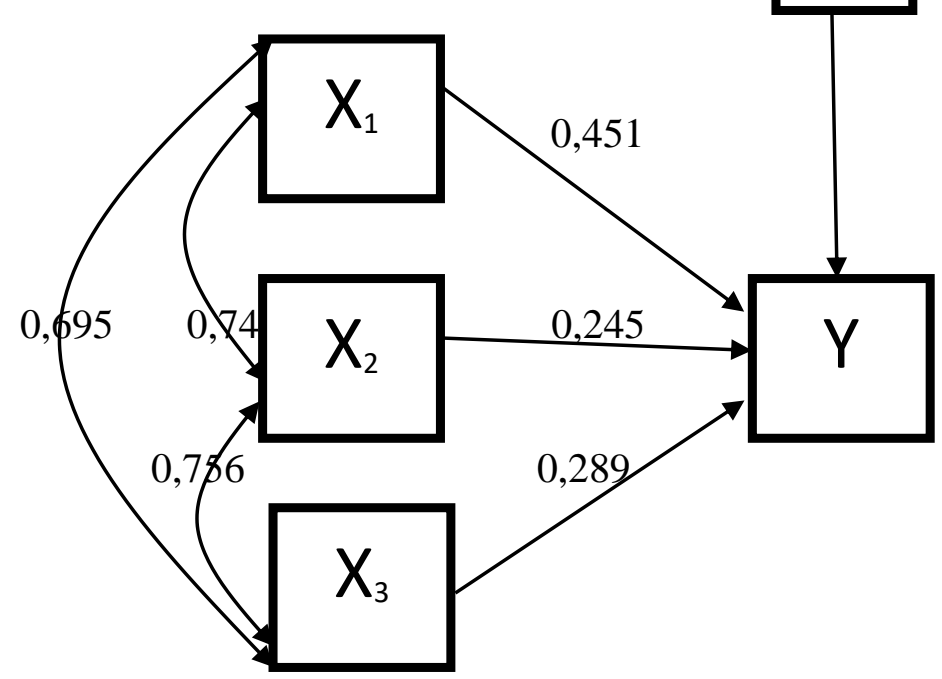




\section{Gambar 4 \\ Koefisien Jalur Variabel Kepemimpinan $\left(\mathbf{X}_{1}\right)$ \\ Motivasi $\left(\mathbf{X}_{2}\right)$ dan Komunikasi $\left(\mathbf{X}_{3}\right)$ terhadap Kinerja Pegawai (Y)}

Berdasarkan gambar menunjukan bahwa besaran derajat positif asosiatif atau koefisien jalur variabel Kepemimpinan 0,451 lebih tinggi dari variabel Motivasi 0,245 dan Variable Komunikasi 0,289, artinya Kepemimpinan $\left(\mathrm{X}_{1}\right)$ lebih berpengaruh terhadap Kinerja pegawai (Y) dibandingkan dengan Motivasi $\left(\mathrm{X}_{2}\right)$ dan Komunikasi $\left(\mathrm{X}_{3}\right)$. Adapun persamaan jalurnya adalah sebagai berikut:

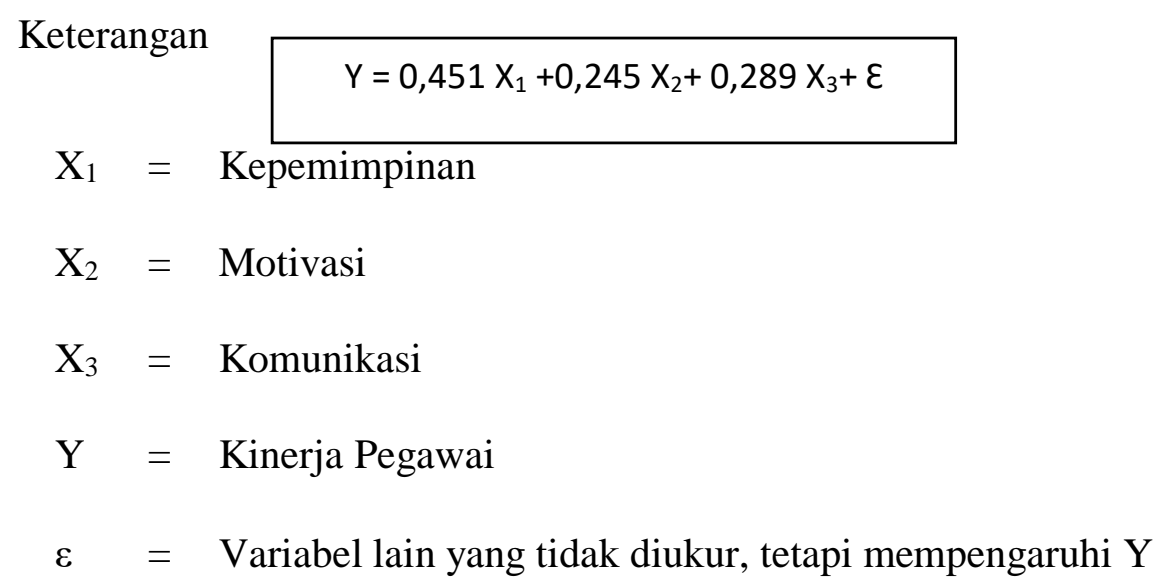

\section{Pengujian Hipotesis}

\section{Pengaruh secara Parsial Kepemimpinan ( $\left.\mathrm{X}_{1}\right)$ terhadap Kinerja Pegawai (Y)}

Pengaruh Kepemimpinan secara parsial terhadap Kinerja Pegawai dapat diketahui melalui pengujian statistik dengan menggunakan hipotesis sebagai berikut:

Hipotesis Statistik:

$\mathrm{H} 0: \rho \mathrm{yx}_{1}=0$ (tidak ada pengaruh)

$\mathrm{H}_{1}: \rho \mathrm{x}_{1} \neq 0$ (ada pengaruh)

Hipotesis Kalimat

$H_{0}: \rho x_{1} x_{2}=0$ Kepemimpinan tidak berpengaruh terhadap kinerja

$H_{1}: \rho x_{1} x_{2} \neq 0$ Kepemimpinan berpengaruh terhadap kinerja

Kriteria Uji: Tolak $\mathrm{H}_{\mathrm{o}}$ jika Sig. $<\alpha$ atau $\mathrm{t}_{\text {hitung }}>\mathrm{t}_{\text {tabel }}$

Untuk pengaruh Kepemimpinan secara parsial terhadap Kinerja pegawai dengan tingkat signifikan $(\alpha)=5 \%$, degree of freedom $(\mathrm{df})=(\mathrm{n}-2)=151-2=149$ diperoleh $\mathrm{t}_{\text {tabel }}=1,976$. Berdasarkan tabel 4.62 di atas, menunjukan bahwa $t_{\text {hitung }}=7.784$ dan sig. 0,000. Pengaruh $\mathrm{X}_{1}$ secara Parsial terhadap Y diperlihatkan pada tabel sebagai berikut:

\section{Tabel 10}

Pengaruh Parsial

Kepemimpinan $\left(\mathrm{X}_{1}\right)$ terhadap Kinerja Pegawai (Y)

\begin{tabular}{|c|c|c|r|r|r|}
\hline Structural & Sig. & $\boldsymbol{\alpha}$ & $\mathbf{t}_{\text {hitung }}$ & $\mathbf{t}_{\text {tabel }}$ & Kesimpulan \\
\hline pyx $_{1}$ & 0,000 & 0,05 & 7.784 & 1,976 & $\mathrm{H}_{\mathrm{o}}$ ditolak \\
\hline
\end{tabular}

Sumber : Hasil Pengolahan Data, 2017

Tabel diatas menunjukan bahwa nilai sig. $(0,000)>\alpha(0,05)$ dan $t_{\text {hitung }}(7.784)>t_{\text {tabel }}$ $(1,976)$ maka $\mathrm{H}_{\mathrm{o}}$ ditolak. Dengan demikian dapat disimpulkan bahwa Kepemimpinan secara parsial berpengaruh positif dan signifikan terhadap Kinerja Pegawai.

\section{Pengaruh Parsial Motivasi $\left(\mathbf{X}_{2}\right)$ terhadap Kinerja Pegawai (Y)}

Pengaruh Motivasi secara parsial terhadap Kinerja Pegawai dapat diketahui melalui pengujian statistik dengan menggunakan hipotesis sebagai berikut : 
Hipotesis statistik:

$H_{0}: \rho y x_{2}=0$ (tidak ada pengaruh)

$H_{1}: \rho y x_{2} \neq 0$ (ada pengaruh)

Hipotesis bentuk kalimat:

$H_{0}$ : Motivasi kerja tidak berpengaruh terhadap kinerja

$H_{1}$ : Motivasi kerja berpengaruh terhadap kinerja

Kriteria Uji : Tolak $\mathrm{H}_{\mathrm{o}}$ jika Sig. $<\alpha$ atau $\mathrm{t}_{\text {hitung }}>\mathrm{t}_{\text {tabel }}$

Untuk pengaruh Motivasi secara parsial terhadap Kinerja Pegawai dengan tingkat signifikan $(\alpha)=5 \%$, degree of freedom $(\mathrm{df})=(\mathrm{n}-2)=151-2=149$ diperoleh $\mathrm{t}_{\text {tabel }}=1,976$. Berdasarkan tabel 4.62 di atas, menunjukan bahwa thitung $=3.852$ dan sig. 0,000. Pengaruh $\mathrm{X}_{2}$ secara parsial terhadap $\mathrm{Y}$ diperlihatkan pada tabel sebagai berikut:

\section{Tabel 11}

\section{Pengaruh Parsial}

Motivasi $\left(\mathbf{X}_{2}\right)$ terhadap Kinerja Pegawai (Y)

\begin{tabular}{|l|l|l|l|l|c|}
\hline Structural & Sig. & $\boldsymbol{\alpha}$ & $\mathbf{t}_{\text {hitung }}$ & $\mathbf{t}_{\text {tabel }}$ & Kesimpulan \\
\hline $\mathrm{Pyx}_{2}$ & 0,000 & 0,05 & 3.852 & 1,976 & $\mathrm{H}_{\mathrm{o}}$ ditolak \\
\hline
\end{tabular}

Sumber : Hasil Pengolahan Data, 2017

Tabel diatas menunjukan bahwa nilai sig. $(0,000)<\alpha(0,05)$ dan $t_{\text {hitung }}(3.852)>t_{\text {tabel }}$ $(1,976)$ maka $\mathrm{H}_{\mathrm{o}}$ ditolak. Dengan demikian dapat disimpulkan bahwa Motivasi secara parsial berpengaruh positif dan signifikan terhadap Kinerja pegawai.

\section{Pengaruh Parsial Komunikasi (X3) terhadap Kinerja Pegawai (Y)}

Pengaruh Komunikasi secara parsial terhadap Kinerja Pegawai dapat diketahui melalui pengujian statistik dengan menggunakan hipotesis sebagai berikut :

Hipotesis statistik:

$H_{0}: \rho y x_{2}=0$ (tidak ada pengaruh)

$H_{1}: \rho y x_{2} \neq 0$ (ada pengaruh)

Hipotesis bentuk kalimat:

$H_{0}$ : Komunikasi tidak berpengaruh terhadap kinerja

$H_{1}$ : Komunikasi berpengaruh terhadap kinerja

Kriteria Uji : Tolak $\mathrm{H}_{\mathrm{o}}$ jika Sig. $<\alpha$ atau $\mathrm{t}_{\text {hitung }}>\mathrm{t}_{\text {tabel }}$

Untuk pengaruh Komunikasi secara parsial terhadap Kinerja Pegawai dengan tingkat signifikan $(\alpha)=5 \%$, degree of freedom $(\mathrm{df})=(\mathrm{n}-2)=151-2=149$ diperoleh $\mathrm{t}_{\text {tabel }}=1,976$. Berdasarkan tabel 4.62 di atas, menunjukan bahwa thitung $=4.879$ dan sig. 0,000. Pengaruh $\mathrm{X}_{2}$ secara parsial terhadap Y diperlihatkan pada tabel sebagai berikut:

\section{Tabel 12}

Pengaruh Parsial

Komunikasi ( $\mathrm{X}_{3}$ ) terhadap Kinerja Pegawai (Y)

\begin{tabular}{|l|l|l|l|l|l|}
\hline Structural & Sig. & $\mathbf{A}$ & thitung & $\mathbf{t}_{\text {tabel }}$ & Kesimpulan \\
\hline $\mathrm{Pyx}_{3}$ & 0,000 & 0,05 & 4.879 & 1,976 & Hoditolak \\
\hline
\end{tabular}

Sumber : Hasil Pengolahan Data, 2017

Tabel diatas menunjukan bahwa nilai sig. $(0,000)<\alpha(0,01)$ dan $t_{\text {hitung }}(4.879)>t_{\text {tabel }}$ $(1,976)$ maka $\mathrm{H}_{0}$ ditolak. Dengan demikian dapat disimpulkan bahwa Komunikasi secara parsial berpengaruh positif dan signifikan terhadap Kinerja Pegawai.

\section{Pengaruh Variable Secara Simultan}


Pengaruh Kepemimpinan $\left(\mathrm{X}_{1}\right)$, Motivasi $\left(\mathrm{X}_{2}\right)$ dan Komunikasi $\left(\mathrm{X}_{3}\right)$ secara simultan (keseluruhan) terhadap Kinerja Pegawai (Y) dapat diketahui melalui pengujian statistik dengan menggunakan hipotesis sebagai berikut:

Hipotesis statistik:

$H_{0}: \rho y x_{1}=\rho y x_{2}=\rho y x_{3}=0$ (tidak ada pengaruh)

$H_{1}: \rho y x_{1} \neq \rho y x_{2} \neq \rho y x_{3} \neq 0$ (ada pengaruh)

Hipotesis bentuk kalimat:

$H_{0}$ : Kepemimpinan, motivasi kerja dan komunikasi secara simultan tidak berpengaruh terhadap kinerja

$H_{1}$ : Kepemimpinan, motivasi kerja dan komunikasi secara simultan berpengaruh terhadap kinerja.

Kriteria Uji : Tolak $\mathrm{H}_{\mathrm{o}}$ jika Sig. $<\alpha$ atau $\mathrm{t}_{\text {hitung }}>\mathrm{f}_{\text {tabel }}$

Untuk pengaruh Kepemimpinan, Motivasi dan Komunikasi secara simultan terhadap

Kinerja Pegawai dengan tingkat signifikan $(\alpha)=5 \%$, degree offreedom $(\mathrm{df})=(\mathrm{n}-2)=151$

$-2=149$, diperoleh $\mathrm{f}_{\text {tabel }}=3,09$. Sedangkan $\mathrm{f}_{\text {hitung }}$ dapat dilihat pada tabel di bawah ini :

Tabel 13

Hasil Perhitungan Nilai F

ANOVA ${ }^{a}$

\begin{tabular}{|c|c|c|c|c|c|c|}
\hline \multicolumn{2}{|c|}{ Model } & $\begin{array}{c}\text { Sum of } \\
\text { Squares }\end{array}$ & df & $\begin{array}{l}\text { Mean } \\
\text { Square }\end{array}$ & $\mathrm{F}$ & Sig. \\
\hline 1 & $\begin{array}{l}\text { Regress } \\
\text { ion }\end{array}$ & 7372.253 & 3 & $\begin{array}{r}2457.41 \\
8\end{array}$ & $\begin{array}{r}195 . \\
575\end{array}$ & $.000^{\mathrm{b}}$ \\
\hline & $\begin{array}{l}\text { Residu } \\
\text { al }\end{array}$ & 1847.071 & 147 & 12.565 & & \\
\hline & Total & 9219.324 & 150 & & & \\
\hline
\end{tabular}

a. Dependent Variable: KINERJA

Sumber

b. Predictors: (Constant), KOMUNIKASI, KEPEMIMPINAN, MOTIVASI : Hasil

Pengolahan Data, 2017

Berdasarkan tabel di atas, menunjukan bahwa $f_{\text {hitung }}=195.575$ dan sig. 0,000. Pengaruh Kepemimpinan (X1), Motivasi (X2) dan Komunikasi $\left(\mathrm{X}_{3}\right)$ secara simultan terhadap Kinerja Karyawan (Y) diperlihatkan pada tabel di bawah ini :

Tabel 14

Pengaruh Simultan Kepemimpinan $\left(\mathbf{X}_{1}\right)$, Motivasi $\left(\mathbf{X}_{2}\right)$

Dan Komunikasi $\left(\mathbf{X}_{3}\right)$ terhadap Kinerja Pegawai $(\mathrm{Y})$

\begin{tabular}{|l|l|l|l|l|l|}
\hline Structural & Sig. & A & fhitung & f tabel & Kesimpulan \\
\hline $\operatorname{Pyx}_{1}, \mathrm{X}_{2, \mathrm{X} 3}$ & 0,000 & 0,05 & 195.575 & 3,06 & $\mathrm{H}_{\mathrm{o}}$ ditolak \\
\hline
\end{tabular}

Sumber : Hasil Pengolahan Data, 2017

Tabel diatas menunjukan bahwa nilai sig. $(0,000)<\alpha(0,05)$ dan $f_{\text {hitung }}(195.575)>f_{\text {tabel }}$ $(3,06)$ maka $\mathrm{H}_{\mathrm{o}}$ ditolak. Dengan demikian dapat disimpulkan bahwa Kepemimpinan, Motivasi dan Komunikasi secara simultan berpengaruh positif dan signifikan terhadap Kinerja Pegawai.

\section{F. SIMPULAN}

Berdasarkan hasil penelitian, pengumpulan data dan pembahasan yang dilakukan peneliti pada Dinas Lingkungan Hidup dan Kebersihan Kabupaten Karawang, maka dapat di ambil kesimpulan sebagai berikut :

1. Kepemimpinan di Dinas Lingkungan Hidup Dan Kebersihan sudah sesuai kebutuhan pegawai, karena Indikator yang diteliti dengan total skor dari 10 indikator sebesar 5,478 
dan nilai rata-rata yaitu 547,8, dengan rentang skala 513,5-634,3 berada pada kriteria setuju. Hal ini menunjukan persepsi pegawai pada Dinas Lingkungan Hidup dan Kebersihan Kabupaten Karawang menyatakan setuju terhadap Kepemimpinansudah berjalan baik.Motivasidi Dinas Lingkungan Hidup yang di berikan kepada pegawai sudah baik, karenayang diteliti dengan total skor 5.905 dan rata-rata 536,8, pada rentang skala 513,5-634,3 berada pada kriteria setuju. Hal ini menunjukan persepsi pegawai pada Dinas Lingkungan Hidup dan Kebersihan Kabupaten Karawang menyatakan setuju terhadap Motivasi yang diberikan kepada pegawaisudah berjalan baik. Komunikasi di Dinas Lingkungan Hidupsudah berjalan dengan baikkarena indikator yang diteliti dengan total skor 6.934 dengan rata-rata 533,4, pada rentang skala 513,5634,3 berada pada kriteria setuju. Hal ini menunjukan persepsi pegawai pada Dinas Lingkungan Hidup dan Kebersihan Kabupaten Karawang menyatakan setuju terhadap komunikasi antar pegawai sudah berjalan baik. Kinerja Pegawai di Dinas Lingkungan Hidup sudah memiliki kinerja yang baik, karena indikator yang diteliti dengan total skor 7.651 rata-rata 546,5, pada rentang skala 513,5-634,3 pada kriteria setuju. Hal ini menunjukan persepsi pegawai pada Dinas Lingkungan Hidup dan Kebersihan Kabupaten Karawang menyatakan setuju terhadap Motivasi yang diberikan kepada pegawaisudah berjalan baik.

2. Kepemimpinan secara parsial mempunyai pengaruh yang positif dan signifikan terhadap Kinerja. Dengan Koefisien jalur sebesar 0,451dan besar total pengaruhnya (langsung + tidak langsung) sebesar 0,369 atau 36,9\%.Kepemimpinan lebih banyak memberikan pengaruh terhadap Kinerja dibandingkan variabel Motivasi dan Komunikasi. Hal ini disebabkan karena responden mempunyai pandangan Kepemimpinan sangat mempengaruhi Kinerja, jika Kepemimpinan di nilai tidak bagus oleh para pegawai, maka pegawai tidak akan memiliki kinerja yang baik.

3. Motivasi secara parsial mempunyai pengaruh yang positif dan signifikan terhadap Kinerja dengan Koefisien jalur sebesar 0,245. dan besar total pengaruhnya (langsung + tidak langsung) sebesar 0,196 atau 19,6\%.

4. Komunikasi secara parsial mempunyai pengaruh yang positif dan signifikan terhadap Kinerja. Dengan koefisien jalur sebesar 0,289. dan besar total pengaruhnya (langsung + tidak langsung) sebesar 0,229 atau 22,9\%.

5. Kepemimpinan, Motivasi dan Komunikasisecara simultan berpengaruh positif dan signifikan terhadap Kinerja Pegawai. Total pengaruh Kepemimpinan, Motivasi dan Komunikasi terhadap Kinerja Pegawaiyaitu sebesar 0,794 atau 79,4\% adapun pengaruh variabel lain diluar model adalah sebesar 0,206 atau 20,6\%.

\section{G. SARAN}

Berdasarkan dari hasil penelitian yang dilakukan dan dalam kesempatan ini penulis akan sedikit memberikan beberapa saran, diharapkan dapat menjadi bahan masukan dan bahan pertimbangan bagi Dinas Lingkungan Hidup dan Kebersihan Kabupaten Karawang yang sifatnya untuk kemajuan perusahaan tersebut:

1. Diharapkan pimpinan Dinas Lingkungan Hidup terus meningkatkan kepemimpinan yang ada terutama pada indikator Dukungan dari bawahan, memberi kewenangan dan Koordinasi karena memiliki skor yang rendah diantara indikator yang lain supaya lebih baik lagi serta pegawai lebih nyaman dalam bekerja. Diharapkan Dinas Lingkungan Hidup dan kebersihan dapat terus meningkatkan motivasi pegawai terutama pada inidikator Hasil pekerjaan, Pengakuan dari Teman, kepuasan kerja dan kepercayaan karena masih memliki skor yang rendah dibanding variabel lain supaya motivasi pegawai lebih baik lagi dalam bekerja. Diharapkan Dinas Lingkungan Hidup dan Kebersihan kabupaten karawang agar dapat meningkatkan komunikasi terutama pada 
inidikator dasar pemikiran, menyampaikan informasi, menyampaikan pertanyaan dan koordinasi tugas agar segala informasi mengenai pekerjaan dapat tersalurkan dengan baik. Diharapkan Dinas Lingkungan Hidup dan kebersihan dapat meningkatkan Kinerja Pegawai terutama pada indikator kerjasama dengan atasan dan semangat kerja karena masih meiliki skor lebih rendah dibandingkan indikator lain agar proses pelayanan terhadap masyarakat dapat berjalan dengan baik.

2. Dari penelitian yang telah dilakukan terhadap pengaruh parsial antara kepemimpinan terhadap Kinerja. Diharapkan Dinas Lingkungan Hidup dan Kebersihan Kabupaten Karawang dapat terus meningkatkan kepemimpinan karena dengan kepemimpinan yang baik motivasi pegawai dapat lebih baik lagi

3. Diharapkan DInas Lingkungan Hidup terus meningkatkan motivasi kerja pegawainya karena terdapat pengaruh parsial antara Motivasi terhadap Kinerja. Karena dengan motivasi yang tinggi maka pegawai tentunya akan memiliki kinerja yang tinggi pula sehingga tujua perusahaan dapat tercapai

4. Diharapkan Dinas Lingkungan Hidup dan Kebersihan Kabupaten Karawang terus menjaga dan meningkatkan komunikasi yang ada karena terdapat Pengaruh parsial Komunikasi Terhadap Kinerja. Karena jika komunikasi dapat berjalan dengan baik maka informasi mengenai pekerjaan yang disampaikan pimpinan dari atasan ke bawahan atau sebaliknya dapat diterima dengan baik.

5. Diharapkan untuk penelitian lebih lanjut meneliti variabel lain yang mempengaruhi kinerja tetapi tidak diteliti seperti lingkungan kerja dan budaya organisasi, sehingga diharapkan kinerja pegawai semakin meningkat dan sebagai pertimbangan bagi organisasi dalam menentukan kebijakan yang akan ditetapkan.

\section{H. DAFTAR PUSTAKA}

\section{Buku Dan Jurnal}

Ambar teguh sulistiyani, Rosidah. 2009. Manajemen Sumber Daya Manusia Konsep

Teori dan Pengembangan dalam konteks organisasi public. Bandung: Graha Ilmu.

Bangun, Wilson.2012.Manajemen Sumber Daya Manusia. Jakarta: Erlangga

Buku Pedoman Penyusunan Tugas Akhir Mahasiswa S2 Manajemen. 2015. Fakultas Ekonomi Universitas Singaperbangsa Karawang

Buku Pedoman Penyusunan Tugas Akhir Mahasiswa S2 Manajemen. 2015. Fakultas Ekonomi Universitas Singaperbangsa Karawang

Fahmi, Irham, 2011. Manajemen Kinerja. Edisi ke Satu, Penerbit Alfabeta, Bandung. Handoko, T Hani. 2008. Manajemen. Edisi 2. BPFE, Yogyakarta.

2012. Manajemen. BPFE, Yogyakarta.

Hasibuan, Malayu. S. P. 2011 Manajemen dasar Pengertian dan Masalah Edisi Revisi .Jakarta: Bumi Aksara

Lili Wahyuni, 2009. pengaruh komunikasi organisasi terhadap kinerja karyawan bagian akuntansi dengan komitmen organisasi dan tekanan pekerjaan sebagai variabel intervening. Tesis Program Pascasarjana Universitas Diponegoro (Diakses Tanggal 05 Mei 2017, 10:53).

Mangkunegara, A.A Anwar Prabu. 2008. Manajemen Sumber Daya Manusia Perusahaan. Bandung: Remaja Rosda karya.

Manullang. 2012. Dasar-Dasar Manajemen. Yogyakarta: UGM Gajah Mada University Press

M. Kiswanto, 2010. Pengaruh Kepemimpinan Dan Komunikasi Terhadap Kinerja Karyawan Kaltim Pos Samarinda. JURNAL EKSIS Vol.6 No.1, Maret 2010, ISSN 0216-6437 Politeknik Negeri Samarinda. (Diakses Tanggal 9 Mei 2017, 12:59) 
Murty, Aprilia Windy dan Gunasti Hudiwinarsih. 2012. Pengaruh Kompensasi, Motivasi Dan Komitmen Organisasional Terhadap Kinerja Karyawan Bagian Akuntansi (Studi Kasus Pada Perusahaan Manufaktur Di Surabaya). Jurnal Volume 2, No. 2. ISSN 2086-3802 STIE Perbanas Surabaya (Diakses 10 Mei 2017. 01.03)

Rahmat Sugianto. 2010. Pengaruh Kepemimpinan Manajerial Motivasi dan Komunikasi terhadap kinerja pegawai di Dinas Pendidikan Nasional Provinsi Jawa Barat. Tesis UPI Bandung. (Diakses Tanggal 3 Mei 2017, 04.20)

Ririvega Kasenda. 2013. Kompensasi dan motivasi pengaruhnya terhadap kinerja karyawan pada PT. Bangun wenang beverages company manado. Jurnal EMBA Vol.1 No.3. ISSN 2303-1174 Fakultas Ekonomi Jurusan Manajemen Universitas Sam Ratulangi. (Diakses Tanggal 11 Mei 2017, 04.20)

Rivai,Veithzal. 2011. Manajemen Sumber Daya Manusia untuk Perusahaan. Jakarta: Rineka Cipta. . 2012. Manajemen Sumber Daya Manusia untuk Perusahaan. Jakarta: Rineka Cipta.

Susiati Purwaning Utami. 2010. pengaruh kepemimpinan, motivasi dan komunikasi interpersonal terhadap kinerja karyawan pada biro perjalanan wisata"panen tour". Jurnal Ilmiah WIDYA, Volume 3 Nomor 1 Januari-Agustus 2015, ISSN 2337-6686, STIA Yappann. (Diakses Tanggal 6 Mei 2017. 00.02)

Sembiring, Masana. 2012. Budayadan Kinerja Organisasi. Focus media: Bandunng Siswanto, HB. 2010. Pengantar Manajemen. Jakarta: Bumi Aksara Silalahi, Uber. 2012. Metode Penelitian Sosial. Bandung: Refika Aditama Sopiah. 2008. Perilaku Organisasi. Edisi kesatu. Yogyakarta : Andi Sugiyono, 2012. Metode Penelitian Kuantitatif, Kualitatif, dan $R \&$ D. Penerbit Alfabeta, Bandung.

Sutrisno, Edy. 2009. Manajemen Sumber Daya Manusia. Jakarta: Kencana.

Suwatno \& Donni Juni Priansa. 2011. Manajemen SDM Dalam Organisasi Publik dan Bisnis, Alfabeta, Bandung.

Soelaiman Sukmalana. 2009. Manajemen Kinerja. Jakarta: Bumi Aksara

Usman, Husaini. 2011. Manajemen Teori Praktik dan Riset Pendidikan. Jakarta:Bumi Aksara

Wijaya, Tanto dan Fransiska andreani. 2015. Pengaruh Motivasi dan Kompensasi Terhadap Kinerja Karyawan Pada PT Sinar Jaya Abadi Bersama. Jurnal Vol. 3 No. 2. Universitas Kristen Petra Surabaya. (Diakses Tanggal 12 Mei 2017. 00.02)

Wiludjeng, Sri. 2007. Pengantar Manajemen. Yogyakarta: Graha Ilmu

Wayne, Pace, Don F Faules. 2010. Komunikasi Organisasi (Strategi Meningkatkan Kinerja Perusahaan). Editor Deddy Mulyana. Bandung: Remaja Rosdakarya

Zaenal Mustafa Elqadri, Priyono, Rahayu Puji Suci \& Teddy Chandra. 2015. Effect of Leadership Style, Motivation, and Giving Incentives on the Performance of Employees-PT. Kurnia Wijaya Various Industries. International Education Studies; Vol. 8, No. 10; 2015 ISSN 1913-9020 E-ISSN 1913-9039 Faculty of Economics, University of Islam Indonesia Yogyakarta. (Diakses Tanggal 13 Mei 2017. 00.02)

\section{Peraturan, Kebijakan dan Buku Pedoman}

1. Undang-undang Nomor 32 Tahun 2004 tentang Pemerintahan Daerah

2. Peraturan Daerah Nomor 6 tahun 2014 tentang Organisasi Perangkat Daerah Kabupaten Karawang 